\title{
Effects of Chromium and Tungsten Additions on the Characteristic Properties of New High Magnetic Permeability Alloys "Nimalloy" in the System of Nickel and Manganese*
}

\author{
By Hakaru Masumoto**, Yûetsu Murakami** \\ and Masakatsu Hinai**
}

\begin{abstract}
Since the discovery of high magnetic permeability alloys "Nimalloy", a series of experiments has been carried out on the effects of additions of various elements on the properties of Nimalloy, and the highest initial permeability of 76000 and the highest maximum permeability of 441000 have been obtained in the case of $\mathrm{Cr}$ additions to $\mathrm{Ni}-\mathrm{Mn}-\mathrm{Fe}$ alloys. In the present investigation, it has been found that with increasing $\mathrm{Gr}$ and $\mathrm{W}$ additions to Ni-Mn binary alloys the cooling rate at which the highest permeability is attained becomes smaller gradually. Therefore, in most cases, the alloys were slow-cooled from $900^{\circ} \mathrm{C}$ and further baked for a long time at a temperature below the order-disorder transformation point. With increasing contents of $\mathrm{Gr}$ and W, both the initial and maximum permeabilities of the alloys increased gradually to the maximum values and afterwards decreased gradually. By the addition of $\mathrm{Cr}$, the alloy composed of $80.93 \% \mathrm{Ni}, 17.13 \% \mathrm{Mn}$ and $1.94 \% \mathrm{Cr}$ showed the highest value of 17000 in initial permeability and the alloy of $80.47 \% \mathrm{Ni}, 17.30 \% \mathrm{Mn}$ and $2.23 \% \mathrm{Cr}$, the highest value of 103000 in maximum permeability. In the case of $\mathrm{W}$ addition, the alloy composed of $76.65 \% \mathrm{Ni}, 19.23 \% \mathrm{Mn}$ and $4.12 \% \mathrm{~W}$ showed the highest values of 13720 in initial permeability and 60700 in maximum permeability.
\end{abstract}

(Received June 3, 1969)

\section{Introduction}

Masumoto et al. (1) discovered previously that $\mathrm{Ni}$ Mn alloys containing less than about $24 \% \mathrm{Mn}$ exhibits high permeabilities when their ferromagnetic superlattice $\mathrm{Ni}_{3} \mathrm{Mn}$ is in optimum ordered state by suitable heat treatments. These alloys were named "Nimalloy". A series of experiments has ever since been conducted on the variations of the characteristics of $\mathrm{Ni}-\mathrm{Mn}$ alloys by the addition of $\mathrm{Fe}^{(2)}, \mathrm{V}^{(3)}, \mathrm{Si}^{(4)}, \mathrm{Al}^{(5)}, \mathrm{Ti}^{(6)}, \mathrm{Sb}^{(7)}$, $\mathrm{Mo}^{(8)}, \mathrm{Cr}^{(9)}, \mathrm{Sn}^{(10)}, \mathrm{W}^{(11)}, \mathrm{Co}^{(11)}, \mathrm{Cu}^{(11)}, \mathrm{Gr}^{(12)}, \mathrm{Nb}^{(12)}$ or $\mathrm{Ta}^{(13)}$ as the third element and those of $\mathrm{Ni}-\mathrm{Mn}-\mathrm{Fe}$ alloys by the addition of $\mathrm{Cr}^{(14)}$ or $\mathrm{Mo}^{(15)}$ as the fourth

* This paper was presented at the Meetings of the Japan Institute of Metals, October 2, 1964, Toyama and October 18, 1965, Fukuoka, Japan. The 26 th report from The Foundation: The Research of Electric and Magnetic Alloys, Sendai, Japan. To be published in Japanese in J. Japan Inst. Metals, 33 (1969), $235 ; 33$ (1969), 488 .

** The Foundation: The Research Institute of Electric and Magnetic Alloys, Sendai, Japan.

(1) H. Masumoto, T. Kobayashi and Y. Murakami : J. Japan Inst. Metals, 29 (1965), 228; Trans. JIM, 8 (1967), 49.

(2) H. Masumoto, T. Kobayashi and Y. Murakami : J. Japan Inst. Metals, 29 (1965), 1101; Trans. JIM, 8 (1967), 54.

(3) H. Masumoto, T. Kobayashi and Y. Murakami : J. Japan Inst. Metals, 30 (1966), 837 ; Trans. JIM, 8(1967), 264.

(4) H. Masumoto, T. Kobayashi and Y. Murakami : J. Japan Inst. Metals, 31 (1967), 1117; Trans. JIM, 9 (1968), 355.

(5) H. Masumoto, Y. Murakami and M. Hinai : J. Japan Inst. Metals, 32 (1968), 444; Trans. JIM, 10 (1969), 115.

(6) H. Masumoto, T. Kobayashi and Y. Murakami : J. Japan Inst. Metals, 32 (1968), 521 ; Trans. JIM, 9 (1968), 355.

(7) H. Masumoto, Y. Murakami and M. Hinai : J. Japan Inst. Metals, 32 (1968), 856 ; Trans. JIM ,10 (1969), 247.

(8) H. Masumoto, T. Kobayashi and Y. Murakami : Presented at the Spring Meeting of the Japan Institute of Metals, Apr. 5, 1964, Tokyo, Japan.

Trans. J I M element. In consequence, the highest initial permeability of 76000 and the highest maximum permeability of 441000 were obtained in the case of $\mathrm{Cr}$ additions to $\mathrm{Ni}-\mathrm{Mn}-\mathrm{Fe}$ alloys. Further, from measurements of the saturation magnetostriction $\lambda_{s}{ }^{(16) \sim(18)}$ and the crystal magnetic anisotropy energy $K_{1}{ }^{(19)(20)}$, it has been made clear that both values of $\lambda_{s}$ and $K_{1}$ are very small in the

(9) H. Masumoto, Y. Murakami and M. Hinai : J. Japan Inst. Metals, 33 (1969), 235.

(10) H. Hasumoto, Y. Murakami and M. Hinai : J. Japan Inst. Metals, 33 (1969), ;130; Trans. JIM, 10 (1969), 247.

(11) H. Masumoto, Y. Murakami and M. Hinai : J. Japan Inst. Metals, 33 (1969), 488.

(12) H. Masumoto, Y. Murakami and M. Hinai : Presented at the Spring Meeting of the Japan Institute of Metals, Apr. 6, 1966, Tokyo, Japan.

(13) H. Masumoto, Y. Murakami and M. Hinai : Presented at the Spring Meeting of the Japan Institute of Metals, Mar. 30, 1969, Tokyo, Japan.

(14) H. Masumoto, Y. Murakami and M. Hinai : Presented at the Autumn Meeting of the Japan Institute of Metals, Oct. 17, 1966, Amagasaki, Japan.

(15) H. Masumoto, Y. Murakami and M. Hinai : Presented at the Autumn Meeting of the Japan Institute of Metals, Oct. 1, 1967, Sapporo, Japan.

(16) H. Masumoto, T. Kobayashi and S. Kadowaki : Presented at the Autumn Meeting of the Japan Institute of Metals, Oct.19, 1963, Nagoya, Japan.

(17) H. Masumoto, Y. Murakami and S. Kadowaki : Presented at the Autumn Meeting of the Japan Institute of Metals, Oct. 2, 1964, Toyama, Japan.

(18) H. Masumoto, Y. Murakami and S. Kadowaki : Presented at the Spring Meeting of the Japan Institute of Metals, Apr. 6, 1965, Tokyo, Japan.

(19) H. Masumoto, Y. Murakami and N. Nakamura : Presented at the Spring Meeting of the Japan Institute of Metals, Apr. 6, 1966, Tokyo, Japan.

(20) H. Masumoto, Y. Murakami and N. Nakamura : Presented at the Autumn Meeting of the Japan Institute of Metals, Oct. 17, 1966, Amagasaki, Japan. 
composition range over which the high permeabilities are attained.

The present paper deals with the results of additions of $\mathrm{Cr}$ and $\mathrm{W}$ to Nimalloy.

\section{Specimens and Experimental Procedure}

The alloying elements used were electrolytic Ni, electrolytic Mn, 99.8\% pure $\mathrm{Cr}$ and $99.9 \%$ pure W. The former two were the same in purity as those used in the previous work ${ }^{(1)}$. The methods of preparation and measurement were entirely the same as reported previously $^{(1)}$, so that description on them are omitted here. The Ni-Mn-Cr alloy specimens used were 100 kinds in composition of $75.67 \sim 97.28 \% \mathrm{Ni}, 0 \sim 22.17 \% \mathrm{Mn}$ and $0.50 \sim 6.47 \% \mathrm{Cr}$, while the $\mathrm{Ni}-\mathrm{Mn}-\mathrm{W}$ alloy specimens were 90 kinds in composition of $70.29 \sim 94.42 \% \mathrm{Ni}$, $3.95 \sim 23.35 \% \mathrm{Mn}$ and $1.63 \sim 11.87 \% \mathrm{~W}$.

\section{Experimental Results and Consideration}

\section{Ni-Mn-Cr alloys}

The experimental results are summarized in Table 1 and Figs. $1 \sim 10$. The specimens whose compositions are indicated by solid circles in Figs. $1 \sim 2$ were heated in vacuum at $900^{\circ} \mathrm{C}$ for $1 \mathrm{hr}$ and then cooled to room temperature at the specified cooling rates of $9^{\circ} \mathrm{C} / \mathrm{sec}, 240^{\circ}$, $10^{\circ}, 5^{\circ}, 3^{\circ}$ and $0.75^{\circ} \mathrm{C} / \mathrm{hr}$, respectively. Depending on the kinds of the spacimens, some of them were cooled to room temperature at a rate of $5^{\circ} \mathrm{C} / \mathrm{hr}$ and baked at various temperatures below the order-disorder transformation point. The equi-values curves of these figures are statistically drawn against the alloy composition, using the highest values of $\mu_{0}$ and $\mu_{m}$ measured at room temperature for each of the alloys examined. It is evident from the figures that by the addition of $\mathrm{Cr}$ to $\mathrm{Ni}-\mathrm{Mn}$ alloys, $\mu_{0}$ and $\mu_{m}$ increase gradually at the beginning and

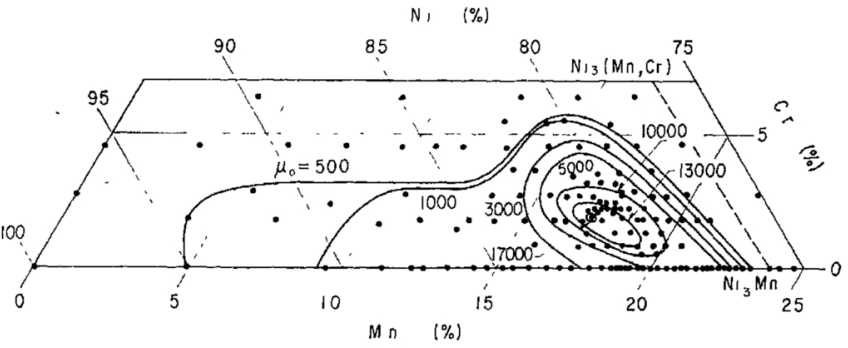

Fig. 1 Highest initial permeability in each of $\mathrm{Ni}-\mathrm{Mn}-\mathrm{Cr}$ alloys cooled at various rates from $900^{\circ} \mathrm{C}$ or further baked at various temperatures

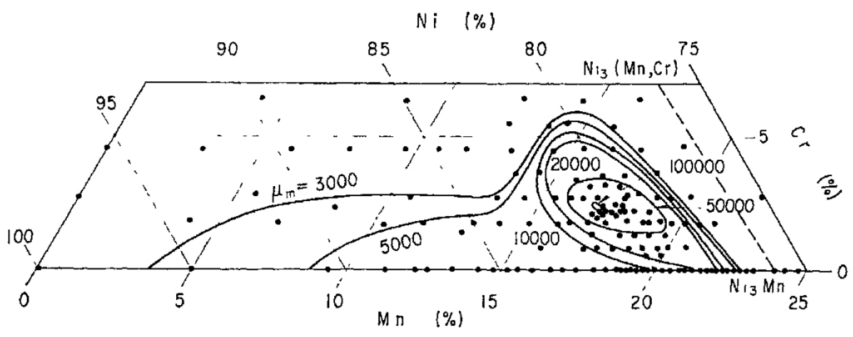

Fig. 2 Highest maximum permeability in each of $\mathrm{Ni}-\mathrm{Mn}-\mathrm{Cr}$ alloys cooled at various rates from $900^{\circ} \mathrm{C}$ or further baked at various temperatures

Table 1 Magnetic and electric properties of typical Ni-Mn-Cr alloys

\begin{tabular}{|c|c|c|c|c|c|c|c|c|c|c|c|c|c|c|c|c|}
\hline \multirow{2}{*}{$\begin{array}{c}\text { Alloy } \\
\text { No. }\end{array}$} & \multirow{2}{*}{$\begin{array}{l}\text { Mn } \\
(\%)\end{array}$} & \multirow{2}{*}{$\begin{array}{l}\mathrm{Cr} \\
(\%)\end{array}$} & \multirow{2}{*}{$\begin{array}{l}\text { Cooling } \\
\text { rate } \\
\text { from } \\
900^{\circ} \mathrm{C} \\
\left({ }^{\circ} \mathrm{C} / \mathrm{hr}\right)\end{array}$} & \multicolumn{2}{|l|}{ Baking } & \multirow[t]{2}{*}{$\mu_{0}$} & \multirow[t]{2}{*}{$\mu_{m}$} & \multirow{2}{*}{$\begin{array}{c}B(\mathbf{G}) \\
\text { for } \\
\mu_{m}\end{array}$} & $\begin{array}{l}W_{h} \\
(\mathrm{erg} / \\
\mathrm{cm}^{3} / \\
\text { cycle) }\end{array}$ & $\begin{array}{l}B_{r} \\
(G)\end{array}$ & $\begin{array}{c}H_{c} \\
(\mathrm{Oe})\end{array}$ & $\begin{array}{c}4 \pi I_{900} \\
(G)\end{array}$ & $\begin{array}{c}\lambda_{s} \\
\left(\times 10^{-6}\right)\end{array}$ & \multirow{2}{*}{$\begin{array}{c}\sigma \\
(\mu \Omega- \\
\mathrm{cm}, \\
\left.20^{\circ} \mathrm{G}\right)\end{array}$} & \multirow{2}{*}{$\begin{array}{c}\alpha \\
\left(\times 10^{-3}\right. \\
0^{\circ} \sim \\
\left.40^{\circ} \mathrm{C}\right)\end{array}$} & \multirow{2}{*}{$\begin{array}{l}\text { Density } \\
\left(\mathrm{g} / \mathrm{cm}^{3}\right)\end{array}$} \\
\hline & & & & $\begin{array}{c}\text { Temperature } \\
\left({ }^{\circ} \mathrm{C}\right)\end{array}$ & $\begin{array}{l}\text { Time } \\
(\mathrm{hr})\end{array}$ & & & & \multicolumn{3}{|c|}{$\boldsymbol{B}_{m}=4000 \mathrm{G}$} & \multicolumn{2}{|c|}{$H=900 \mathrm{Oe}$} & & & \\
\hline $\begin{array}{l}33 \\
35 \\
37\end{array}$ & $\begin{array}{l}21.63 \\
21.80 \\
22.00\end{array}$ & I & $\begin{array}{r}10 \\
5 \\
10\end{array}$ & 380 & $\frac{50}{50}$ & $\begin{array}{l}6860 \\
5090 \\
5880\end{array}$ & $\begin{array}{l}18000 \\
12490 \\
20400\end{array}$ & $\begin{array}{l}891 \\
626 \\
908\end{array}$ & $\begin{array}{l}* 18.30 \\
* 18.50 \\
* 19.34\end{array}$ & $\begin{array}{r}* 954 \\
* 876 \\
* 1052\end{array}$ & $\begin{array}{l}* 0.0315 \\
* 0.0272 \\
* 0.0270\end{array}$ & \begin{tabular}{|l|}
2790 \\
2760 \\
2804
\end{tabular} & $\begin{array}{l}\overline{0.17} \\
0.00\end{array}$ & $\begin{array}{l}60.7 \\
60.5 \\
60.7\end{array}$ & $\begin{array}{l}0.93 \\
0.94 \\
0.93\end{array}$ & $\overline{8.42}$ \\
\hline 8 & 1921 & 0.84 & 5 & - & $\pi$ & 13030 & 3020 & & & & & & & & & \\
\hline "1 & 19.21 & . & 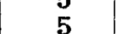 & & $\overline{50}$ & & 302 & 729 & $* 2.82$ & 352 & 0.0103 & & - & & - & - \\
\hline 22 & 17.13 & 1.94 & 5 & 380 & 600 & 17000 & $\begin{array}{l}410000 \\
45000\end{array}$ & $\begin{array}{l}692 \\
692\end{array}$ & $* 7.89$ & $* 876$ & $* 0.0143$ & 3826 & 0.35 & 68.1 & 0.67 & 二 \\
\hline 26 & 18.15 & 1.87 & 5 & & & 11780 & 5400 & 1202 & - & - & - & 4827 & 0.35 & 67.2 & 0.77 & 8.42 \\
\hline 29 & 18.73 & 1.75 & 5 & & & 10780 & 634 & 1975 & 26.98 & 2160 & 0.0247 & & & & & \\
\hline 33 & 19.30 & 1.8 & 5 & & & 88 & 526 & 2336 & 50.87 & 3340 & 0.0401 & 5880 & 0.70 & 68.7 & 0.66 & 8.34 \\
\hline 47 & 16.34 & 2.75 & 5 & & & 93 & 865 & 1307 & 32.35 & 2122 & 0.0145 & 42 & 0.3 & 71.0 & 0.65 & \\
\hline 48 & 16.82 & 2.72 & & 40 & & 10780 & 580 & 1548 & *30.88 & $*_{1200}$ & $* 0.03$ & 447 & 0.3 & 72. & 0.69 & 8.47 \\
\hline & & "I & 5 & 40 & & 68 & 8730 & 2564 & 34.49 & 2135 & & 448 & 0.3 & 70 & 0.6 & - \\
\hline 49 & 16.92 & 2.10 & 5 & 400 & 200 & 147 & 43200 & 961 & $* 7.45$ & $* 1200$ & $* 0.0139$ & 3670 & 0.35 & 68.5 & 0.59 & - \\
\hline 52 & 17.30 & 2.23 & 0.75 & & & & & 972 & - & - & 0 & & & & & \\
\hline & $" 1$ & $" 1$ & & 400 & 400 & 131 & 103 & 1843 & 22.64 & 2643 & 0.0168 & 4550 & 0.70 & 73.8 & 0.31 & 8.43 \\
\hline & & & & & & & & & & & & 4620 & 0.70 & 73.2 & 0.36 & \\
\hline 53 & 17.31 & 2.04 & 5 & 40 & & 13720 & 47200 & 1469 & $* 12.31$ & $* 908$ & $* 0.01$ & - & - & - & - & - \\
\hline 59 & & & 5 & & & & & & & 335 & & 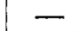 & 一 & - & - & - \\
\hline & & & 5 & & & 10300 & 60 & 16 & 37.48 & 2896 & 0.0274 & 4527 & 0.52 & 73.3 & 0.52 & - \\
\hline 62 & 1 & 2.9 & 5 & 40 & & 53 & & 20 & & - & - & & & 77 & 0.3 & - \\
\hline 63 & & & 5 & & & & & & 27.75 & 2670 & 0.02 & 48 & 1. & & 0.6 & 一 \\
\hline 64 & & & 5 & & & & 726 & 232 & 31.55 & 2735 & 0.02 & 527 & 1.2 & 70 & 0. & 8.34 \\
\hline 71 & .75 & 3.42 & 5 & 40 & 4 & 73 & 420 & 748 & $* 18.37$ & $* 1475$ & $* 0.0351$ & 38 & 0.7 & 77 & 0.2 & \\
\hline 72 & & & 5 & 40 & & & 780 & 1522 & 24.39 & 2283 & & 498 & 0.3 & 72 & 0.7 & 8.42 \\
\hline 73 & & & 5 & 40 & & & 450 & 144 & 40.02 & 213 & 0.0 & 48 & 1. & 77 & 0.5 & 8.40 \\
\hline 74 & & 3.1 & 5 & 40 & 4 & & & 16 & 31.28 & 213 & 0.0 & 44 & 0.2 & 74 & 0.37 & 8.43 \\
\hline 75 & & 3.5 & 5 & 420 & & & & 1735 & 63.20 & 225 & 0.064 & 5566 & 1.7 & 80.3 & 0.5 & - \\
\hline 87 & 15.40 & 4.56 & & 420 & 350 & 2500 & 32400 & 1442 & 74.80 & 2670 & 0.0694 & 5610 & 1.05 & 84.7 & 0.44 & 8.47 \\
\hline
\end{tabular}

$* B_{m}=2000 \mathrm{G}$ 
attain the maxima, and then decrease drastically. The highest values of permeability obtained are 17000 in $\mu_{0}$ for the alloy composed of $80.93 \% \mathrm{Ni}, 17.13 \% \mathrm{Mn}$ and $1.94 \% \mathrm{Cr}$ and 103000 in $\mu_{m}$ for the alloy of $80.47 \%$ $\mathrm{Ni}, 17.30 \% \mathrm{Mn}$ and $2.23 \% \mathrm{Cr}$. These values are by far larger than 6860 in $\mu_{0}$ and 20400 in $\mu_{m}$ obtained on Ni-Mn binary alloys.

Magnetic and electrical properties of the typical alloys in the $\mathrm{Ni}-\mathrm{Mn}-\mathrm{Cr}$ system are tabulated in Table $\mathrm{l}$, where $W_{h}$ is the hysteresis loss, $4 \pi I_{900}$ the magnetic induction at an effective field of $9000 \mathrm{e}, \sigma$ the electrical resistivity and $\alpha$ the temperature coefficient of resistivity. As shown in the table, the addition of $\mathrm{Cr}$ improves greatly the magnetic properties of the $\mathrm{Ni}-\mathrm{Mn}$ alloys, with a relatively large increase in $4 \pi I_{900}$ and $\sigma$.

In the case of $\mathrm{Ni}-\mathrm{Mn}-\mathrm{Cr}$ alloys, the cooling rate at which the highest values of $\mu_{0}$ and $\mu_{m}$ are developed does not show any marked variation against the $\mathrm{Cr}$ content in the composition range of more than about $83 \% \mathrm{Ni}$, whereas in the composition range of less than about $83 \%$ $\mathrm{Ni}$ they decrease rapidly with increasing $\mathrm{Cr}$ content. Fig. 3 indicates an example of the cooling rate dependence of $\mu_{m}$ for the alloy containing about $80.5 \% \mathrm{Ni}$. In the Cr-rich alloys, $\mu_{m}$ does not reach the highest value even if the alloys are subjected to cooling at such a very low rate as $0.75^{\circ} \mathrm{C} / \mathrm{hr}$. Therefore, in order to maximize $\mu_{m}$, it is essentially important to advance the ordering of the alloys by means of baking at temperature below the order-disorder transformation point after slow-cooling from a high temperature.

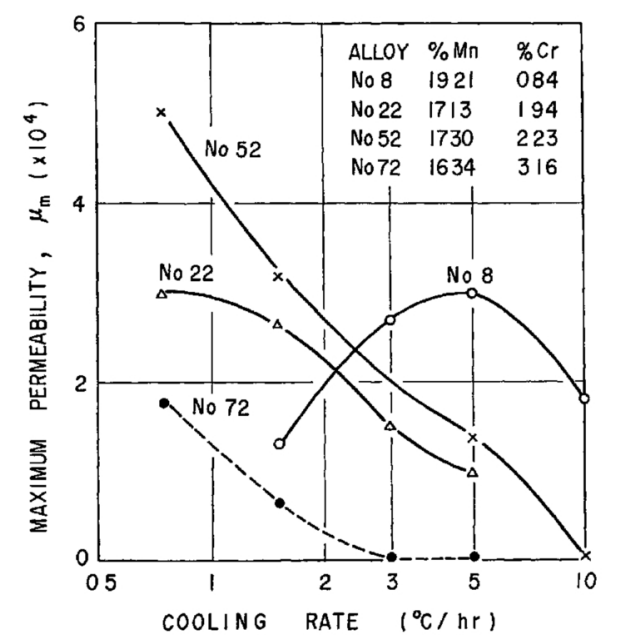

Fig. 3 Effect of cooling rate from $900^{\circ} \mathrm{C}$ on maximum permeability of $\mathrm{Ni}-\mathrm{Mn}-\mathrm{Cr}$ alloys containing about $80.5 \% \mathrm{Ni}$

Fig. 4 illustrates the baking time dependence of $\mu_{0}$ and $\mu_{m}$ for the same alloy as used in Fig. 3 in case of baking at $400^{\circ} \mathrm{C}$ after cooling from $900^{\circ} \mathrm{C}$ at a rate of $5^{\circ} \mathrm{C} / \mathrm{hr}$. In general, each alloy shows the maximum values of $\mu_{0}$ and $\mu_{m}$ against the baking time, and the maxima shift toward a longer baking time with increasing $\mathrm{Cr}$ content. Fig. 5 shows the baking time dependence of $\mu_{0}$ and $\mu_{m}$ for No. 52 alloy of the highest maximum permeability $(80.47 \% \mathrm{Ni}, 17.30 \% \mathrm{Mn}$ and $2.23 \% \mathrm{Cr})$, when baked at various temperatures after cooling from $900^{\circ} \mathrm{C}$ at a $5^{\circ} \mathrm{C} / \mathrm{hr}$. The maximum values of $\mu_{0}$ and $\mu_{m}$ revealed

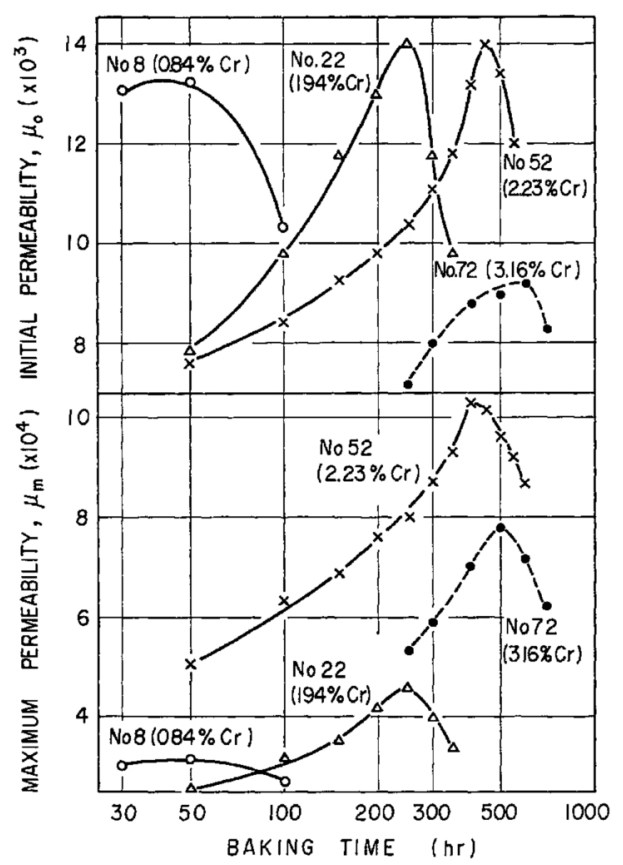

Fig. 4 Effect of baking time at $400^{\circ} \mathrm{C}$ after cooling at $5^{\circ} \mathrm{C} / \mathrm{hr}$ from $900^{\circ} \mathrm{C}$ on initial and maximum permeabilities of $\mathrm{Ni}-\mathrm{Mn}-\mathrm{Cr}$ alloys containing about $80.5 \% \mathrm{Ni}$

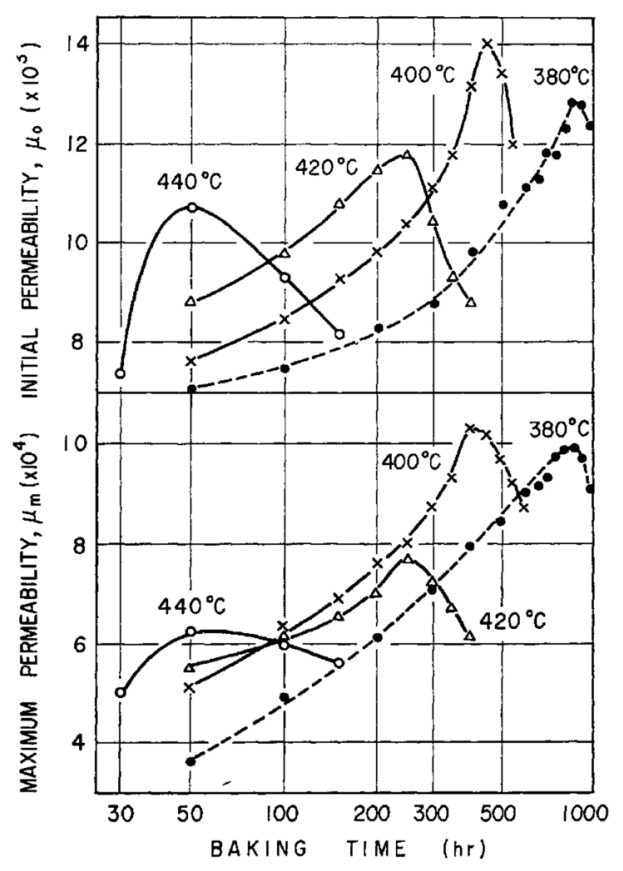

Fig. 5 Effect of baking temperature and time after cooling at $5^{\circ} \mathrm{C} / \mathrm{hr}$ from $900^{\circ} \mathrm{C}$ on initial and maximum permeabilities of $80.47 \% \mathrm{Ni}$ $17.30 \% \mathrm{Mn}-2.23 \% \mathrm{Cr}$ alloy

in each curve of the figure shift toward a shorter baking time with rising baking temperature. The highest values of 14000 in $\mu_{0}$ and 103000 in $\mu_{m}$ were obtained when the alloy was baked at $400^{\circ} \mathrm{C}$ for 450 and $400 \mathrm{hr}$, respectively. In Fig. 6 , the maximum values of $\mu_{0}$ and $\mu_{m}$ obtained by baking at $380^{\circ}, 400^{\circ}$ and $420^{\circ} \mathrm{C}$ after cooling from $900^{\circ} \mathrm{C}$ at a rate of $5^{\circ} \mathrm{C} / \mathrm{hr}$ are schematically represented as a function of $\mathrm{Cr}$ content in the $\mathrm{Ni}-\mathrm{Mn}-\mathrm{Cr}$ alloys containing about $80.5 \% \mathrm{Ni}$. Figs. 4, 5 and 6 indicate clearly that there is an optimum baking 
temperature and time by which a $\mathrm{Ni}-\mathrm{Mn}-\mathrm{Cr}$ ternary alloy can attain the highest values of $\mu_{0}$ and $\mu_{m}$. As can be predicted from the above experimental results on the
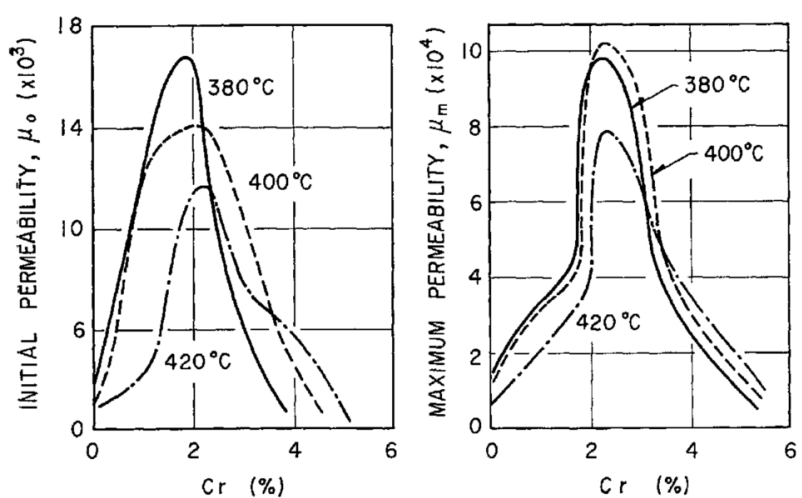

Fig. 6 Maximum values of initial and maximum permeabilities obtained by baking at various temperatures after cooling at $5^{\circ} \mathrm{C} / \mathrm{hr}$ from $900^{\circ} \mathrm{C}$ as a function of $\mathrm{Cr}$ content of $\mathrm{Ni}-\mathrm{Mn}-\mathrm{Cr}$ alloys containing about $80.5 \% \mathrm{Ni}$

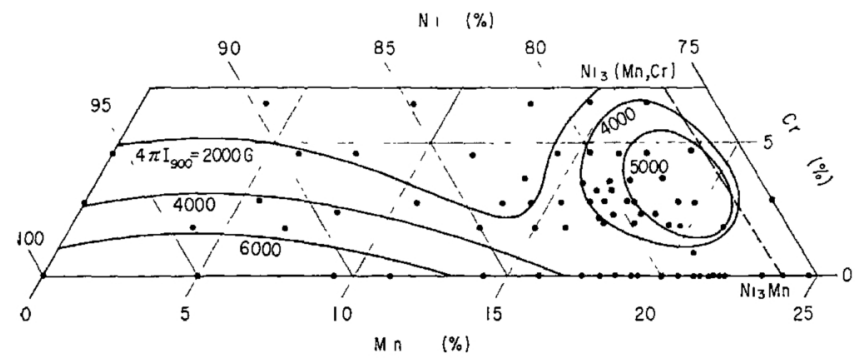

Fig. 7 Magnetic induction at an effective field of $900 \mathrm{Oe}$ in $\mathrm{Ni}-\mathrm{Mn}$-Cr alloys heat-treated to develop the highest maximum permeability

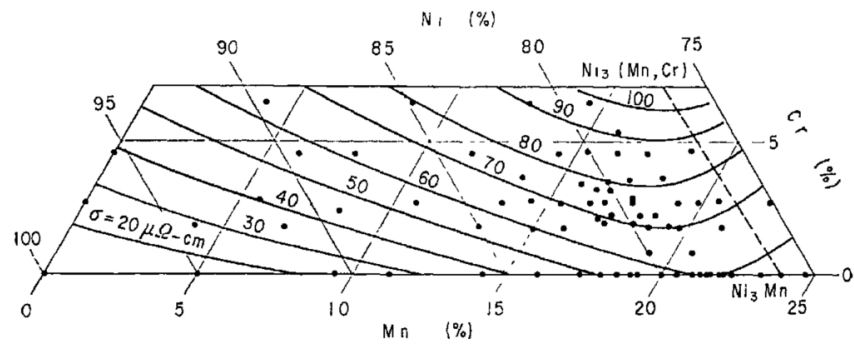

Fig. 8 Electrical resistivity at $20^{\circ} \mathrm{C}$ in $\mathrm{Ni}-\mathrm{Mn}-\mathrm{Cr}$ alloys heattreated to develop the highest maximum permeability

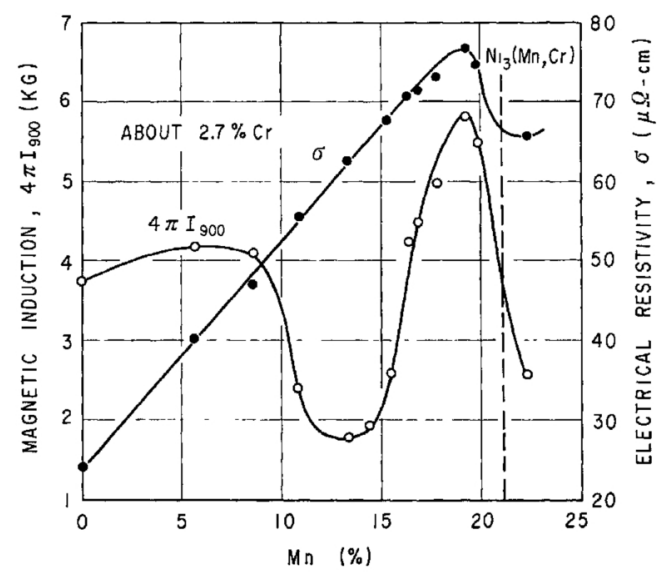

Fig. 9 Magnetic induction and electrical resistivity of $\mathrm{Ni}-\mathrm{Mn}$-about $2.7 \% \mathrm{Cr}$ alloys heat-treated to develop the highest maximum permeability addition of $\mathrm{Cr}$ to $\mathrm{Ni}-\mathrm{Mn}$ alloys, in order to increase the permeability of the alloys, it is necessary to heat them at relatively high temperatures below the order-disorder

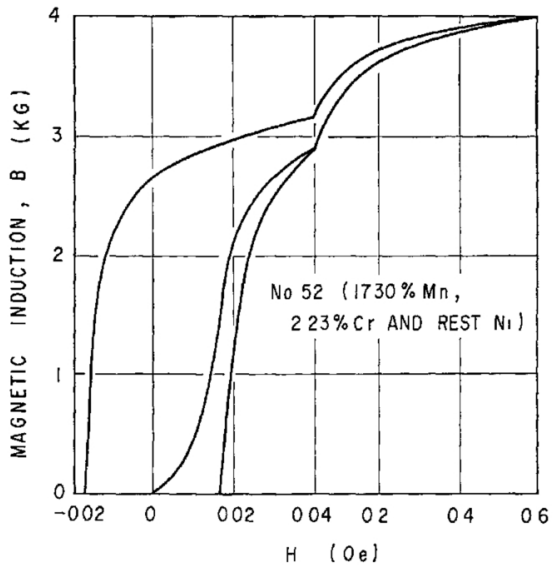

Fig. 10 Magnetization and hysteresis curves of No. 52 alloy baked at $400^{\circ} \mathrm{G}$ for $400 \mathrm{hr}$ after cooling at $5^{\circ} \mathrm{C} / \mathrm{hr}$ from $900^{\circ} \mathrm{C}$

transformation point after slow cooling from high temperature.

Figs. 7 and 8 show the alloy composition dependence of $4 \pi I_{900}$ obtained at $H=900 \mathrm{Oe}$ and $\sigma$ at $20^{\circ} \mathrm{C}$ in each $\mathrm{Ni}-\mathrm{Mn}-\mathrm{Cr}$ alloy heat-treated to develop the highest maximum permeability, and Fig. 9 represents the same relationship in the $\mathrm{Ni}-\mathrm{Mn}-\mathrm{Cr}$ alloys containing about $2.7 \% \mathrm{Cr}$. In these figures, the maximum value of $4 \pi I_{900}$ appears at the $\mathrm{Mn}$ content about $2 \%$ lower than the composition $\mathrm{Ni}_{3}(\mathrm{Mn}, \mathrm{Cr})$, indicating the advance in the ordering of the alloys. Fig. 10 shows magnetization and hysteresis curves of No. 52 alloy $(80.47 \% \mathrm{Ni}$, $17.30 \% \mathrm{Mn}, 2.23 \% \mathrm{Cr}$ ) with the highest value of $\mu_{m}$.

\section{2. $\mathrm{Ni}-\mathrm{Mn}-\mathrm{W}$ alloys}

The experimental results on $\mathrm{N}-\mathrm{M} n-\mathrm{W}$ alloys are summarized in Table 2 and Figs. $11 \sim 21$ corresponding to Table 1 and Figs. $1 \sim 10$ in the case of $\mathrm{Ni}-\mathrm{Mn}-\mathrm{Cr}$ alloys. It can clearly be understood from Figs. 11 and 12 that with increasing $W$ content, the values of $\mu_{0}$ and $\mu_{m}$ increase gradually at the beginning, rises to the maxima, and then decrease slowly. And the composition range of high permeabilities is localized on the higher $\mathrm{Ni}$ side than the line connecting $\mathrm{Ni}_{3} \mathrm{Mn}$ and $\mathrm{Ni}_{3}(\mathrm{Mn}, \mathrm{W})$. The highest values of permeabilities obtained are 13720 in $\mu_{0}$ and 60700 in $\mu_{m}$ for the alloy composed $76.65 \%$ $\mathrm{Ni}, 19.23 \% \mathrm{Mn}$ and $4.12 \% \mathrm{~W}$. These values are considerably large as compared with $\mu_{0}$ and $\mu_{m}$ obtained on Ni-Mn binary alloys. Magnetic and electrical properties of the typical $\mathrm{Ni}-\mathrm{Mn}-\mathrm{W}$ alloys are tabulated in Table 2. As shown in the table, the addition of $\mathbb{W}$ to $\mathrm{Ni}-\mathrm{Mn}$ alloys results in a considerable improvement in $\mu_{0}$ and $\mu_{m}$, with a pronounced increase in $4 \pi I_{900}$.

Figs. 13 and 14 show the cooling rate dependence of $\mu_{0}$ and $\mu_{m}$ from $900^{\circ} \mathrm{C}$ against the $\mathrm{Mn}$ content for $\mathrm{Ni}$ $\mathrm{Mn}-\mathrm{W}$ alloys containing about $4.2 \% \mathrm{~W}$. In these figures, the values of $\mu_{0}$ and $\mu_{m}$ exhibit marked variations in the composition range of about $15 \sim 21 \% \mathrm{Mn}$ with the cooling rate. Both values increase steeply with 
Table 2 Magnetic and electric properties of typical Ni-Mn-W alloys

\begin{tabular}{|c|c|c|c|c|c|c|c|c|c|c|c|c|c|c|c|c|}
\hline \multirow{2}{*}{$\begin{array}{l}\text { Alloy } \\
\text { No. }\end{array}$} & \multirow{2}{*}{$\begin{array}{l}\mathrm{Mn} \\
(\%)\end{array}$} & \multirow{2}{*}{$\begin{array}{l}\mathrm{W} \\
(\%)\end{array}$} & \multirow{2}{*}{$\begin{array}{l}\text { Cooling } \\
\text { rate } \\
\text { from } \\
900^{\circ} \mathrm{C} \\
\\
\left({ }^{\circ} \mathrm{C} / \mathrm{hr}\right)\end{array}$} & \multicolumn{2}{|l|}{ Baking } & \multirow{2}{*}{$\mu_{0}$} & \multirow{2}{*}{$\mu_{m}$} & \multirow{2}{*}{$\begin{array}{c}B(\mathrm{G}) \\
\text { for } \\
\mu_{m}\end{array}$} & $\begin{array}{l}W_{h} \\
\text { (erg/ } \\
\text { cm }^{3} /\end{array}$ & $\begin{array}{r}\boldsymbol{B}_{\boldsymbol{r}} \\
(\mathbf{G})\end{array}$ & $\begin{array}{c}H_{c} \\
(\mathrm{Oe})\end{array}$ & $\begin{array}{c}4 \pi I_{900} \\
(G)\end{array}$ & $\begin{array}{c}\lambda_{s} \\
\left(\times 10^{-6}\right)\end{array}$ & \multirow{2}{*}{$\begin{array}{c}\sigma \\
\\
(\mu \Omega- \\
\mathrm{cm} \\
\left.20^{\circ} \mathrm{C}\right)\end{array}$} & \multirow{2}{*}{$\begin{array}{c}\alpha \\
\left(\times 10^{-3},\right. \\
0^{\circ} \sim \\
\left.40^{\circ} \mathrm{C}\right)\end{array}$} & \multirow{2}{*}{$\begin{array}{l}\text { Density } \\
\left(\mathrm{g} / \mathrm{cm}^{3}\right)\end{array}$} \\
\hline & & & & $\begin{array}{c}\text { Temperature } \\
\left({ }^{\circ} \mathrm{C}\right)\end{array}$ & $\begin{array}{c}\text { Time } \\
(\mathrm{br})\end{array}$ & & & & \multicolumn{3}{|c|}{$B_{m}=5000 \mathrm{G}$} & \multicolumn{2}{|c|}{$H=900 \mathrm{Oe}$} & & & \\
\hline 20 & 19.57 & 2.58 & 5 & - & - & 5400 & 45000 & 1602 & $* 13.00$ & $* 1517$ & $* 0.0241$ & 4152 & 0.17 & 61.9 & 0.92 & 8.61 \\
\hline "I & & " & 5 & & 60 & & & 1522 & & $* 908$ & & 50 & & & & \\
\hline 22 & 19.64 & 2.06 & 5 & & 60 & 103 & 287 & 1049 & $* 11$ & $* 75$ & & 5112 & 0.1 & & 0.93 & 8.52 \\
\hline 25 & 20.00 & 2.91 & 5 & 400 & 30 & & & 15 & & $*_{12}$ & & & & & 0.89 & - \\
\hline 26 & .13 & 2.0 & 5 & & - & 45 & 235 & 10 & & $* 9$ & & 4503 & & & 0.86 & - \\
\hline 35 & 19.24 & 3.49 & 5 & 400 & 60 & 4750 & 514 & 2055 & 133. & 28 & & & & & & 8.65 \\
\hline "I & 11 & " & 5 & 400 & 180 & 12980 & 33400 & 1630 & 50.12 & 14 & & 56 & 0.3 & & 0.8 & - \\
\hline 36 & 19.57 & 3.83 & 5 & & & 39 & 409 & 36 & 81 & 31 & & 62 & & & 1. & \\
\hline 37 & 19.90 & 3.35 & 5 & 400 & 150 & 10300 & & 16 & & & & 57 & & & 0. & 8.59 \\
\hline 51 & 18.73 & 4.80 & 1.5 & $\cdots$ & & 7350 & 48100 & 3640 & 78.40 & & & 6991 & 0.52 & 55.3 & 1.27 & 8.76 \\
\hline 5 & 1 & 4.6 & 1.5 & - & - & 49 & 549 & 34 & 72 & & & & & & & \\
\hline 54 & 1 & & 3 & & & & & 24 & 47 & & & 6232 & 0. & & 0. & 8.74 \\
\hline " & "I & " & 5 & 380 & 280 & 66 & 594 & 2376 & 86. & & & 61 & & & & - \\
\hline II & " & "I & 5 & & & 137 & 464 & & & & & & & & & - \\
\hline 57 & 19.80 & 4.18 & 5 & & & & & 26 & & 32 & & & & & & 8.72 \\
\hline & & & 5 & 380 & 430 & 11250 & 457 & 26 & & 31 & & 7498 & & & & \\
\hline 62 & 17.84 & 5.34 & 1.5 & - & - & 4410 & 378 & 30 & 116.10 & 36 & 0.0 & 7860 & 0.7 & 50 & 1.31 & 8.74 \\
\hline 63 & & & & - & - & 44 & 327 & 28 & 79.92 & 3674 & 0.0580 & 7350 & 1.05 & 55.5 & 1.21 & \\
\hline 70 & & 6. & & - & - & & & 27 & -0 & $\overline{0}$ & $\overline{0}$ & - & & & & 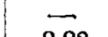 \\
\hline 7 & 18.21 & 6.34 & 0.75 & - & - & 392 & 26200 & 2560 & 58.37 & 4030 & 0.0812 & 8087 & 1.05 & 52.9 & 1.16 & 8.82 \\
\hline
\end{tabular}

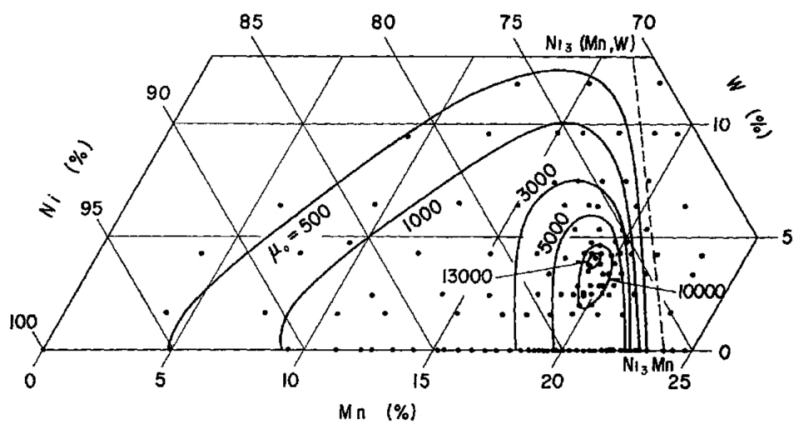

Fig. 11 Highest initial permeability in each of Ni-Mn-W alloys cooled at various rates from $900^{\circ} \mathrm{C}$ or further baked at various temperatures

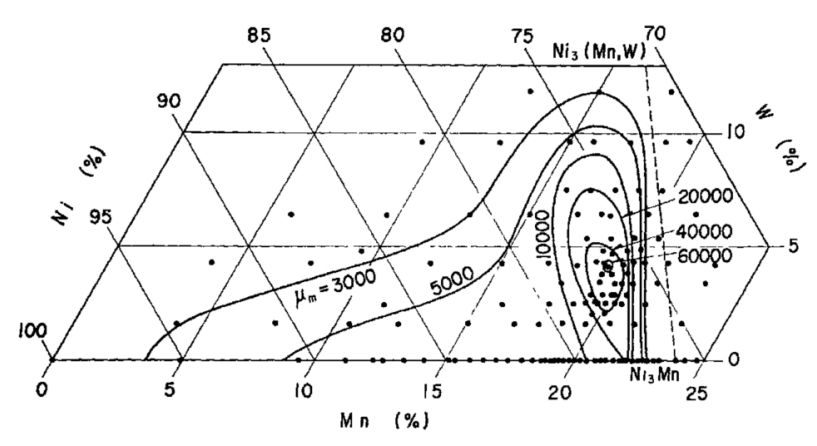

Fig. 12 Highest maximum permeability in each of $\mathrm{Ni}-\mathrm{Mn}-\mathrm{W}$ alloys cooled at various rates from $900^{\circ} \mathrm{C}$ or further baked at various temperatures

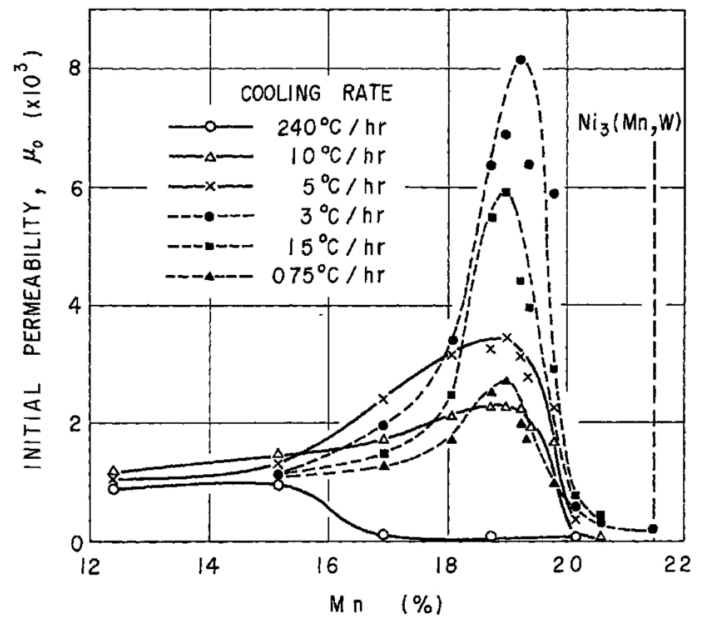

Fig. 13 Initial permeability of Ni-Mn-about $4.2 \% \mathrm{~W}$ alloys cooled at various rates from $900^{\circ} \mathrm{C}$

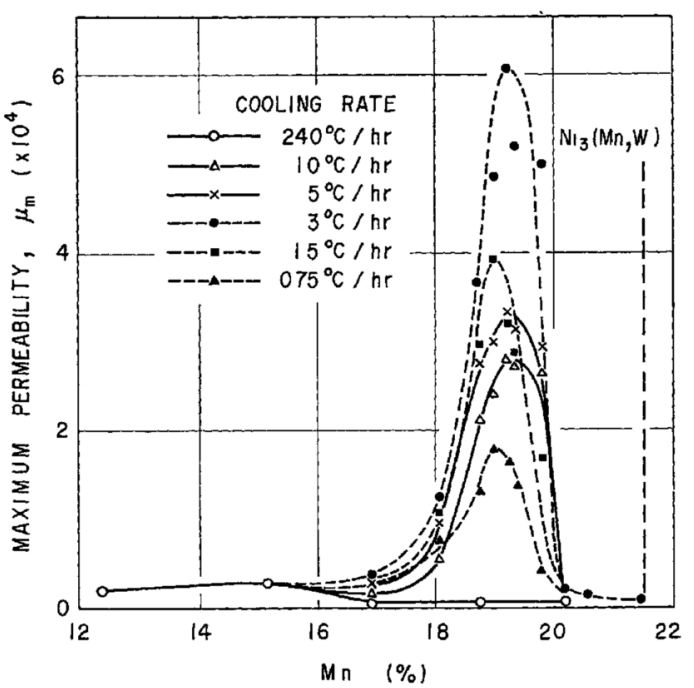

Fig. 14 Maximum permeability of Ni-Mn-about $4.2 \% \mathrm{~W}$ alloys cooled at various rates from $900^{\circ} \mathrm{C}$ 
decreasing cooling rate and attain the maxima at a cooling rate of $3^{\circ} \mathrm{C} / \mathrm{hr}$, and then decrease rapidly. The highest values of $\mu_{0}$ and $\mu_{m}$ obtained are 8090 and 60700 at $19.23 \% \mathrm{Mn}$, respectively. With increasing $\mathrm{W}$ content, the cooling rate at which the highest values of $\mu_{0}$ and $\mu_{m}$ are attained decrease gradually in the $\mathrm{Ni}-\mathrm{Mn}-\mathrm{W}$ alloys containing less than about $81 \% \mathrm{Ni}$. As an example, Fig. 15 shows the cooling rate dependence of $\mu_{0}$ and $\mu_{m}$ for the alloys containing about $76 \% \mathrm{Ni}$.

Fig. 16 shows the baking time dependence of $\mu_{0}$ and

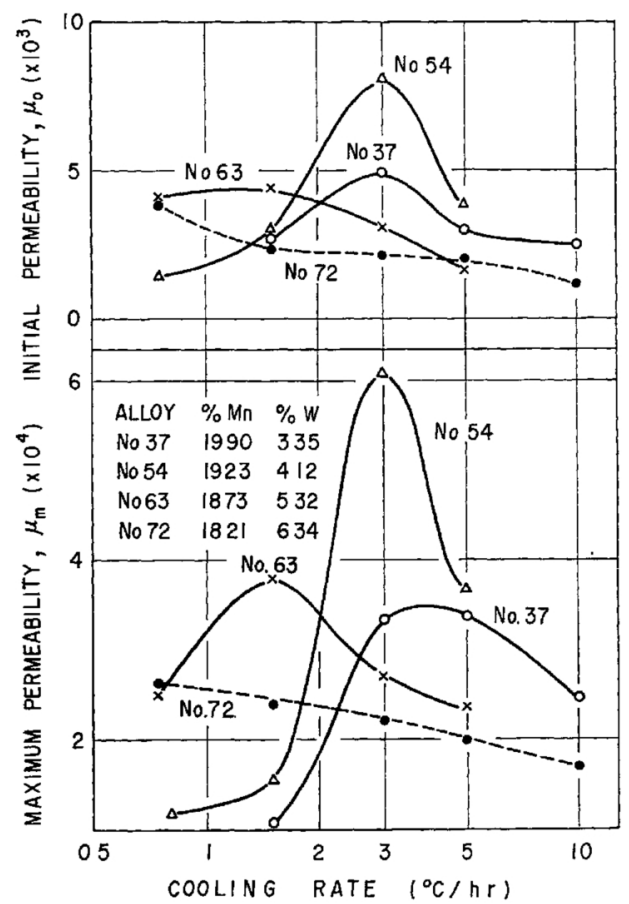

Fig. 15 Effect of cooling rate on initial and maximum permeabilities of $\mathrm{Ni}-\mathrm{Mn}-\mathrm{W}$ alloys containing about $76 \% \mathrm{Ni}$

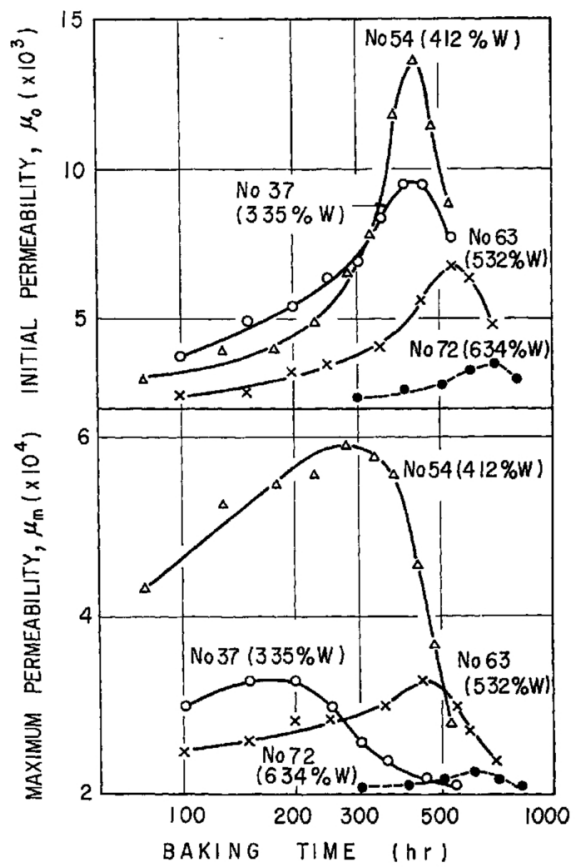

Fig. 16 Effect of baking time at $380^{\circ} \mathrm{C}$ after cooling at a rate of $5^{\circ} \mathrm{C} / \mathrm{hr}$ from $900^{\circ} \mathrm{C}$ on initial and maximum permeabilities of $\mathrm{Ni}-\mathrm{Mn}-\mathrm{W}$ alloys containing about $76 \% \mathrm{Ni}$ $\mu_{m}$ for the same alloys with about $76 \% \mathrm{Ni}$ subjected to baking at $380^{\circ} \mathrm{C}$ after cooling from $900^{\circ} \mathrm{C}$ at a rate of $5^{\circ} \mathrm{C} / \mathrm{hr}$. In general, the permeability exhibits a maximum against the baking time, and the maximum value shifts toward a longer time with increasing $W$ content. Fig. 17 indicates the baking time dependence of $\mu_{0}$ and $\mu_{m}$ for No. 54 alloy $(76.65 \% \mathrm{Ni}, 19.23 \% \mathrm{Mn}, 4.12 \% \mathrm{~W})$ when baked at various temperatures after cooling from $900^{\circ} \mathrm{C}$ at a rate of $5^{\circ} \mathrm{C} / \mathrm{hr}$. The maximum value in each curve of the figure shifts toward a shorter baking time with increasing baking temperature. The highest values of 13720 in $\mu_{0}$ and 59400 in $\mu_{m}$ are shown when

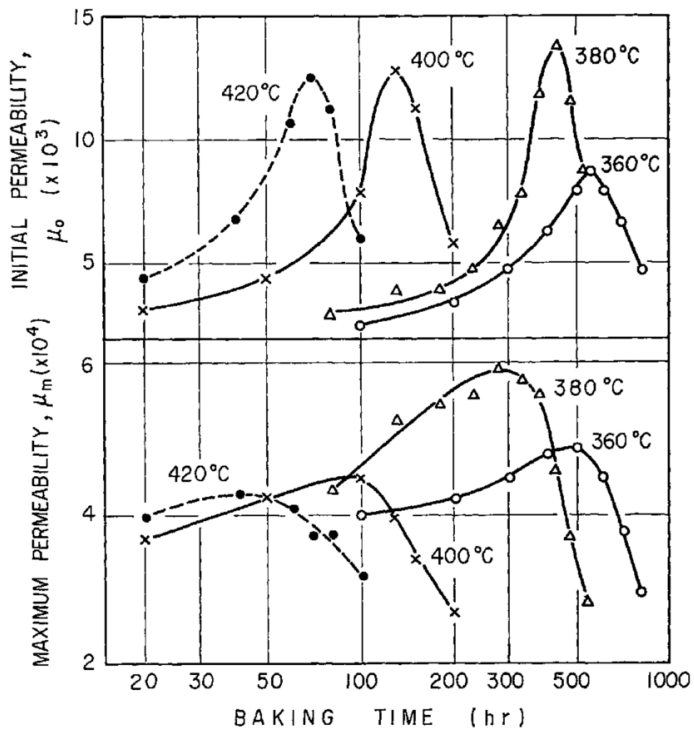

Fig. 17 Effect of baking temperature and time af ter cooling at a rate of $5^{\circ} \mathrm{C} / \mathrm{hr}$ from $900^{\circ} \mathrm{Con}$ initial and maximum permeabilities of No. $54(76.65 \% \mathrm{Ni}-19.23 \%$ $\mathrm{Mn}-4.12 \% \mathrm{~W}$ ) alloy

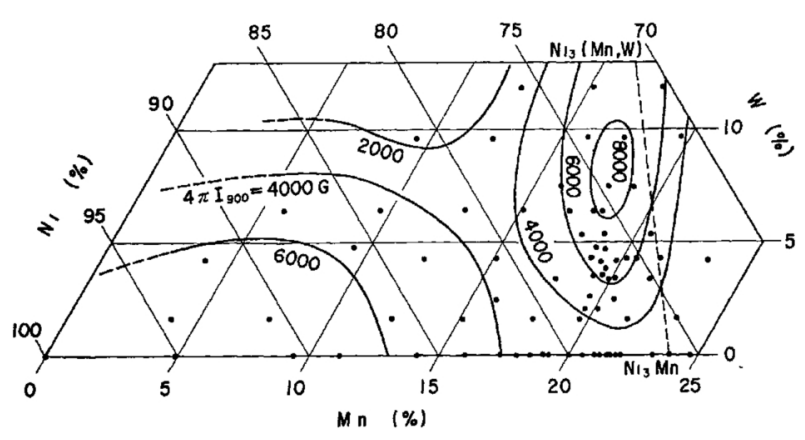

Fig. 18 Magnetic induction at an effective field of $900 \mathrm{Oe}$ in $\mathrm{Ni}-\mathrm{Mn}-\mathrm{W}$ alloys heat-treated to develop the highest maximum permeability

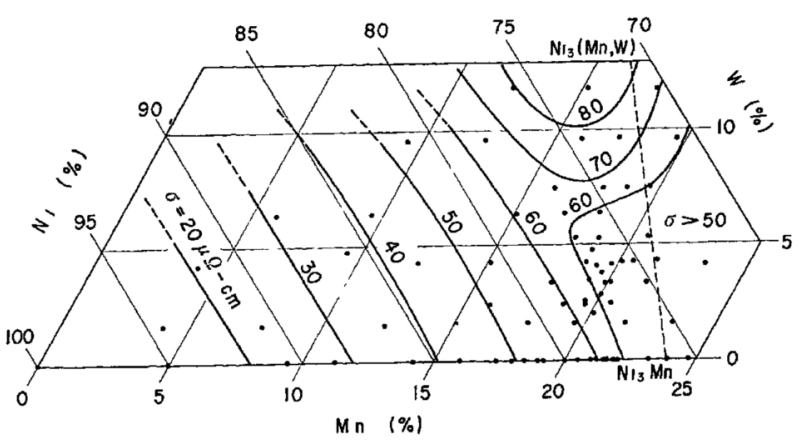

Fig. 19 Electrical resistivity at $20^{\circ} \mathrm{C}$ in $\mathrm{Ni}-\mathrm{Mn}-\mathrm{W}$ alloys heattreated to develop the highest maximum permeability 


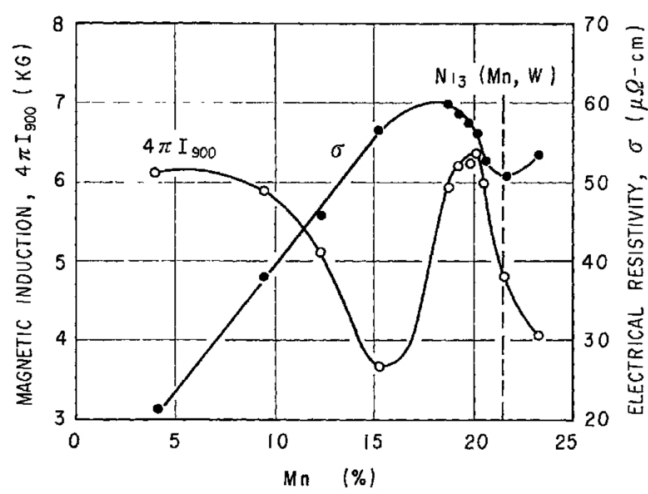

Fig. 20 Magnetic induction and electrical resistivity of Ni-Mn-about $4.2 \% \mathrm{~W}$ alloys heattreated to develop the highest maximum permeability

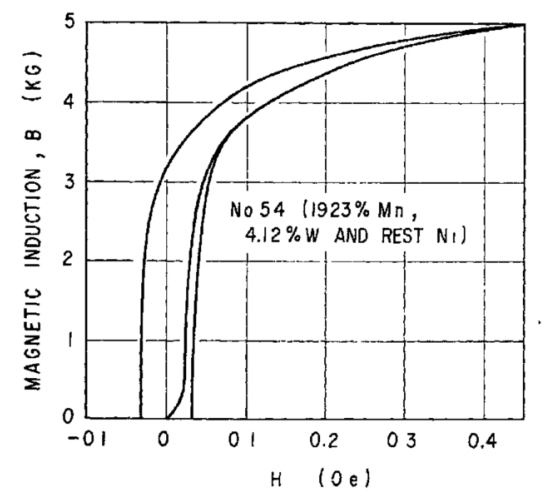

Fig. 21 Magnetization and hysteresis curves of No. 54 alloy cooled at a rate of $3^{\circ} \mathrm{C} / \mathrm{hr}$ from $900^{\circ} \mathrm{C}$

baked at $380^{\circ} \mathrm{C}$ for 430 and $280 \mathrm{hr}$, respectively. Thus, an optimum heat treatment is required for an alloy to develop the highest values of $\mu_{0}$ and $\mu_{m}$. From the above results on the $\mathrm{W}$ addition to $\mathrm{Ni-Mn}$ alloys to obtain the highest permeabilities, these alloys must be baked at temperatures below the order-disorder transformation point after slow cooling from a high temperature.

Figs. 18 and 19 show the alloy composition dependence of $4 \pi I_{900}$ at $H=9000 \mathrm{e}$ and $\sigma$ at $20^{\circ} \mathrm{C}$, respectively, in the $\mathrm{Ni}-\mathrm{Mn}-\mathrm{W}$ alloys heat-treated to develop their highest values of $\mu_{m}$. The same relationship for the Ni-Mn-W alloys containing $4.2 \% \mathrm{~W}$ is given in Fig. 20. In this figure, the fact that $4 \pi I_{900}$ is very large and $\sigma$ is fairly small at the composition of about $20 \% \mathrm{Mn}$ indicates that the ordering of the alloys is taking place to some extent. Fig. 21 shows magnetization and hysteresis curves of No. 54 alloy with the highest value of $\mu_{m}$, when cooled from $900^{\circ} \mathrm{C}$ at a rate of $3^{\circ} \mathrm{C} / \mathrm{hr}$.

lt has been made clear that like other high permeability alloys, high permeability alloys of the $\mathrm{Ni}-\mathrm{Mn}$ $\mathrm{Cr}$ and Ni-Mn-W systems, have very small values of $\lambda_{s}$ as shown in Tables 1 and 2 , respectively.

\section{Conclusions}

100 kinds of $\mathrm{Ni}-\mathrm{Mn}-\mathrm{Cr}$ alloys composed of $75.67 \sim$ $97.28 \% \mathrm{Ni}, 0 \sim 22.17 \% \mathrm{Mn}$ and $0.50 \sim 6.47 \% \mathrm{Cr}$ and 90 kinds of $\mathrm{Ni}-\mathrm{Mn}-\mathrm{W}$ alloys of $70.29 \sim 94.42 \% \mathrm{Ni}$, $3.95 \sim 23.35 \% \mathrm{Mn}$ and $1.63 \sim 11.87 \% \mathrm{~W}$ were heated in vacuum at $900^{\circ} \mathrm{C}$ for $1 \mathrm{hr}$ and then cooled at various rates or further baked at temperatures below the orderdisorder transformation point depending on the kinds of the alloys examined. The following results were obtained from measurements of their magnetic properties, electrical resistivity and its temperature coefficient at room temperature.

(I) The cooling rate at which the highest permeability is attained in the $\mathrm{Ni}-\mathrm{Mn}-\mathrm{Cr}$ alloys containing less than about $83 \% \mathrm{Ni}$ and $\mathrm{Ni}-\mathrm{Mn}-\mathrm{W}$ alloys containing less than about $81 \% \mathrm{Ni}$ becomes smaller with increasing $\mathrm{Cr}$ or $\mathrm{W}$ contents, respectively.

(2) With increasing $\mathrm{Cr}$ or $\mathrm{W}$ contents, the values of $\mu_{0}$ and $\mu_{m}$ increase gradually at the beginning, rises to the maxima, and then decrease gradually. In the case of $\mathrm{Ni}-\mathrm{Mn}-\mathrm{Cr}$ alloys, the highest value of 17000 in $\mu_{0}$ was obtained on the alloy composed of $80.93 \% \mathrm{Ni}, 17.13 \%$ $\mathrm{Mn}$ and $1.94 \% \mathrm{Cr}$ when cooled at a rate of $5{ }^{\circ} \mathrm{C} / \mathrm{hr}$ and baked at $380^{\circ} \mathrm{C}$ for $600 \mathrm{hr}$, and the highest value of 103000 in $\mu_{m}$ on the alloys of $80.47 \% \mathrm{Ni}, 17.30 \% \mathrm{Mn}$ and $2.23 \% \mathrm{Cr}$ when baked at $400^{\circ} \mathrm{C}$ for $400 \mathrm{hr}$ after cooling at a rate of $5^{\circ} \mathrm{C} / \mathrm{hr}$. In the case of $\mathrm{Ni}-\mathrm{Mn}-\mathrm{W}$ alloys, the highest value of 13720 in $\mu_{0}$ was obtained on the alloy of $76.65 \% \mathrm{Ni}, 19.23 \% \mathrm{Mn}$ and $4.12 \% \mathrm{~W}$ when baked at $380^{\circ} \mathrm{C}$ for $430 \mathrm{hr}$ after cooling at a rate of $5^{\circ} \mathrm{C} / \mathrm{hr}$, and the highest value of 60700 in $\mu_{m}$ on the same alloy when cooled at a rate of $3^{\circ} \mathrm{C} / \mathrm{hr}$.

(3) The coercive force of $\mathrm{Ni}-\mathrm{Mn}-\mathrm{Cr}$ and $\mathrm{Ni}-\mathrm{Mn}-\mathrm{W}$ alloys is very small in general. The lowest value of coercive force for a maximum magnetic induction of $4000 \mathrm{G}$ is $0.0145 \mathrm{Oe}$ in the alloy composed of $81.91 \%$ $\mathrm{Ni}, 16.34 \% \mathrm{Mn}$ and $2.75 \% \mathrm{Cr}$, with a hysteresis loss of $32.35 \mathrm{erg} / \mathrm{cm}^{3} / \mathrm{cycle}$. The lowest value of coercive force for a maximum magnetic induction of $5000 \mathrm{G}$ is $0.0321 \mathrm{Oe}$ in the alloy of $76.65 \% \mathrm{Ni}, 19.23 \% \mathrm{Mn}$ and $4.12 \% \mathrm{~W}$, with a hysteresis loss of $47.47 \mathrm{erg} / \mathrm{cm}^{3} / \mathrm{cycle}$.

(4) The magnetic induction and electrical resistivity of $\mathrm{Ni}-\mathrm{Mn}-\mathrm{Cr}$ alloys and $\mathrm{Ni}-\mathrm{Mn}-\mathrm{W}$ alloys are large in general. The Ni-Mn-Cr alloy $(80.47 \% \mathrm{Ni}, 17.30 \%$ $\mathrm{Mn}$ and $2.23 \% \mathrm{Cr})$ and the $\mathrm{Ni}-\mathrm{Mn}-\mathrm{W}(76.65 \% \mathrm{Ni}$, $19.23 \% \mathrm{Mn}$ and $4.12 \% \mathrm{~W}$ ) with the highest value of $\mu_{m}$ in the respective systems show $4550 \mathrm{G}(H=900 \mathrm{Oe})$ and $73.8 \mu \Omega-\mathrm{cm}\left(20^{\circ} \mathrm{C}\right)$, and $6232 \mathrm{G}(H=900 \mathrm{Oe})$ and $58.7 \mu \Omega-\mathrm{cm}\left(20^{\circ} \mathrm{C}\right)$, respectively.

(5) These alloys can more easily be forged and rolled at room and high temperatures than permalloys. 